\title{
Effects of Different Temperatures on the Performance of Seeds Germination of Cecropia pachystachya Trec. (Cecropiaceae)
}

\author{
Rosemari Pilati $^{1 *}$, Izabel de Fátima Andrian ${ }^{2}$ and José W. P. Carneiro ${ }^{3}$ \\ 1 Pós-graduação em Ecologia de Ambientes Aquáticos Continentais, Departamento de Biologia, Nupélia, \\ Universidade Estadual de Maringá, CEP 87020-900 Maringá, PR, Brasil 2. Departamento de Biologia, Nupélia, \\ Universidade Estadual de Maringá, CEP 87020-900 Maringá, PR, Brasil ${ }^{3}$. Departamento de Agronomia, \\ Universidade Estadual de Maringá, CEP 87020-900 Maringá, PR, Brasil
}

\begin{abstract}
Seed germination of Cecropia pachystachya Trec. was investigated at 25,30 , and $35^{\circ} \mathrm{C}$ using fluorescent day lights. Ten replicates each of 200 seeds were used in each thermal treatment. Germitest ${ }^{\circledR}$ paper, CEL-065®, and 11x11x5 $\mathrm{cm}$ Gerbox ${ }^{\circledR}$ were also used. The frequencies of radicle protrusions were counted at consecutive two hour intervals. The cumulative frequencies were combined with the distribution of Weibull using the following model: $\mathrm{Y}=\mathrm{M}\left(1-\exp \left(-(\mathrm{t} / \mathrm{b})^{\mathrm{c}}\right)\right)$. The best performance was achieved with the temperature of $30^{\circ} \mathrm{C}(\mathrm{M}, 95.29 \%)$. Time to achieve $60.23 \%$ of seed germination $(0.6321$ x $95.29 \%)$ was $99.35 \mathrm{~h}$ with a spread of 7.19 . All model/data set combinations had close to linear.
\end{abstract}

Key words: Cecropia pachystachya; seed germination; Weibull function

\section{INTRODUCTION}

Cecropia pachystachya is a pioneer species (Budowski, 1965) occurring from Ceará, Bahia, Minas Gerais, Goiás, and Mato Grosso do Sul to Santa Catarina (Lorenzi, 1992). It is nondeciduous, heliophyte and selective hygrophyte, characteristic of secondary woods. In addition to its value as an ornamental, it is used for recovering of degraded areas (Lorenzi, 1992). The fruits are produced annually in large quantities and are of great importance as food for animals. Although fundamental to knowledge of the species, basic information on factors affecting seed germination performance of $C$. pachystachya is limited and requires additional studies.

Laboratory evaluation methods, carried out under controlled conditions, have been studied and developed in order to obtain regular, rapid, and complete seed germination. For tropical and subtropical tree and shrub species, whose specific requirements are often unknown, no standardized methodology exists, although some research-based information can be found (Figliolia et al., 1993).
The main factor affecting the metabolic processes responsible for germination of forest seeds is the temperature, which is directly associated with the ecological characteristics of the species (Figliolia et al., 1993). Thus, the optimum temperature and the time interval during which germination occurs vary among species. Some require alternating temperatures to germinate, others show responses to a narrow or wide thermal range (Figliolia et al., 1993). Many factors may alter the responses obtained. The physiological condition of the seed (Popinigis, 1977), and the age and origin of the biological material (Lockley, 1980) are the examples. The temperature can also have influence on seedling establishment in tropical forests, and it is a fundamental variable for studies of ecophysiology and plant succession (Figliolia et al., 1993). Appropriate temperatures permit a seed lot to express its maximum germination potential, an aspect of seed quality.

The physiological quality of a seed lot is evaluated by the germination (Ista, 1993), and vigor tests (Popinigis, 1977; Vieira \& Carvalho, 1994). The results expressed using percentage as

Author for correspondence 
well as indices have generated doubts as to its power to discriminate different samples (Brown \& Mayer, 1986, 1988a). In spite of difficulties in quantifying seed germination performance, some mathematical models have been proposed to overcome it. Models of cumulative distribution with the logistic function (Bahler et al., 1989; Dumur et al., 1990), the cumulative normal distribution (Dumur et al., 1990), and other functions (Brown \& Mayer, 1988b) have been compared with the standards used. The model which has the best performance was proposed by Weibull (Weibull, 1951) and studied by several investigators (Brown \& Mayer, 1988b; Bahler et al., 1989; Dumur et al., 1990; Carneiro, 1994a).

The distribution of Weibull permits greater precision in evaluating quality, because the unique expression of percent germination is replaced by parameters with biological meaning (Dumur et al., 1990 Carneiro, 1994a;). Previous results have indicated that this distribution is appropriate for evaluation of the performance of seeds under germination (Carneiro, 1994b; Carneiro \& Guedes, 1995; Takahashi et al., 1996).
The objective of the present investigation was to quantify the germination performance of seeds of Cecropia pachystachya using three temperatures, combining cumulative measurements of germination frequencies with the cumulative distribution of Weibull.

\section{STUDY AREA}

The seeds used in this experiment were obtained from mature fructescences of Cecropia pachystachya Trec., collected from several trees, in fragments of the Semideciduous Seasonal Alluvial and Submontane Forest (Campos \& Souza, 1997). This forest is located on the Upper Paraná River floodplain in the vicinity of the Municipalities of Porto Rico in the State of Paraná, and Taquaruçu in the State of Mato Grosso do Sul $\left(22^{0} 43^{\prime} / 22^{0} 48^{\prime} \mathrm{S}\right.$ and $53^{\circ} 15^{\prime} / 53^{0}$ 20 'W) (Fig. 1).

The regional climate is classified in the Köppen system as Cfa, with a warm summer and the mean temperature of the warmest month is above $22^{\circ} \mathrm{C}$. The annual mean temperature is $22^{\circ} \mathrm{C}$ and annual precipitation is between 1200 to $1300 \mathrm{~mm}$ (Maack, 1981; Campos \& CostaFilho, 1994).

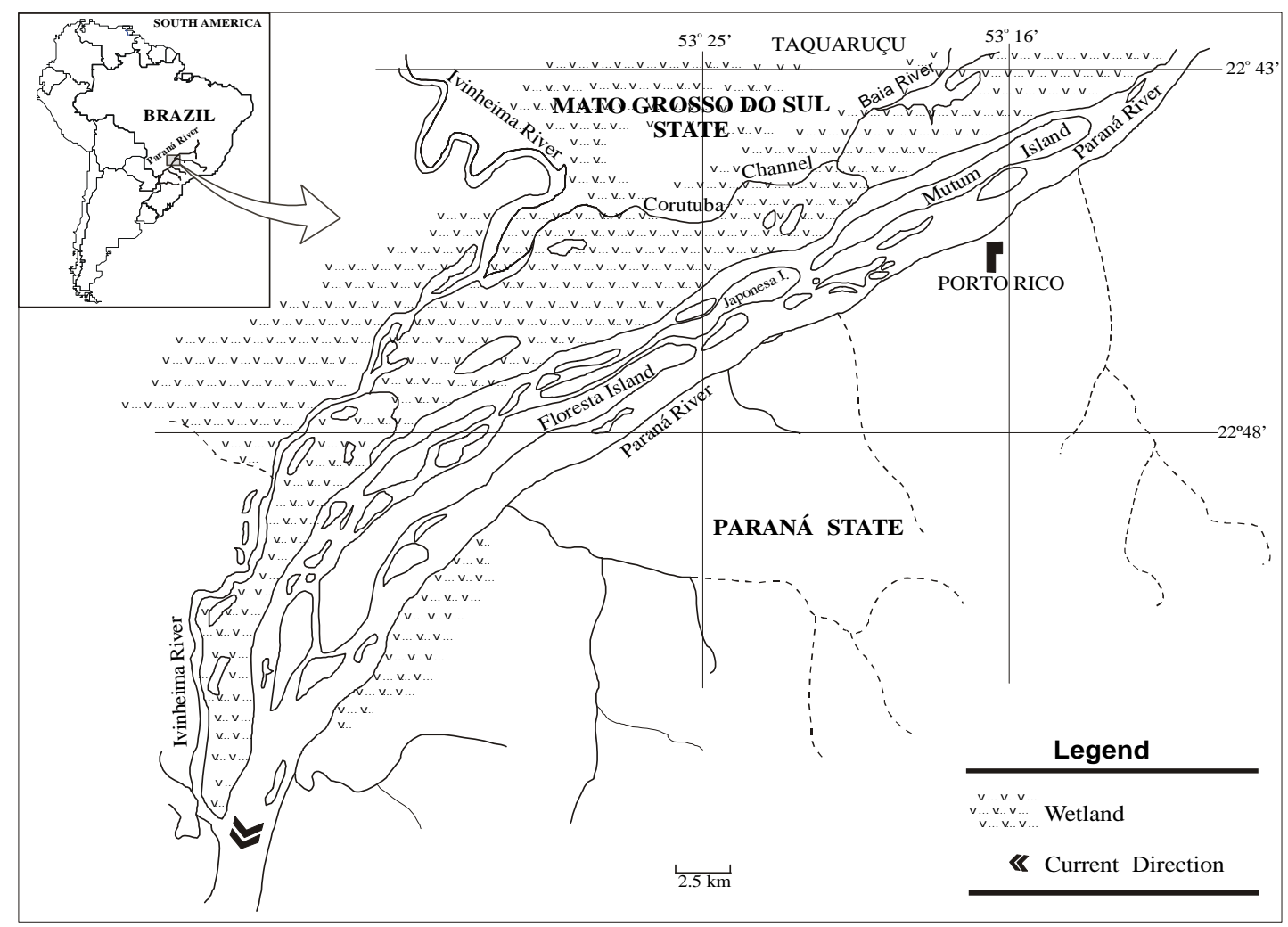

Fig. 1. Location of the study area 


\section{MATERIALS AND METHODS}

The seeds were germinated at constant temperatures of 25,30 , and $35^{\circ} \mathrm{C}$, using germination chambers installed in a room with temperature at $20^{\circ} \mathrm{C} \pm 1^{0} \mathrm{C}$. "Daylight" fluorescent bulbs were kept turned on during the entire period of the experiment. Each treatment consisted of 10 repetitions, each of 200 seeds (Carneiro, 1994b; 1996), distributed uniformly on special germination paper, CEL-065®, in Gerbox ${ }^{\circledR}$ transparent plastic boxes measuring $11 \times 11 \times 5 \mathrm{~cm}$. The substrate was kept humid with distilled deionized water. Germination frequencies were counted at consecutive time intervals of two hours (Carneiro, 1994b). Each seedling with the radicle lenght equal or greater than $3 \mathrm{~mm}$ were classed as germinated, counted and removed from the Gerbox.

\section{Theoretical Foundation}

The variable $\mathrm{T}$ is associated to the time until seed germination occurs. $\mathrm{F}^{*}{ }_{\mathrm{T}}\left(\mathrm{t}_{\mathrm{i}}\right)=\mathrm{P}\left(\mathrm{T}>\mathrm{t}_{\mathrm{i}}\right)$, in that $\quad P\left(T>t_{i}\right)$ indicates the probability that a seed, under test, will not germinate before time $\mathrm{t}_{\mathrm{i}}$, $\mathbf{i}$ being $1,2, \ldots$, and $\mathrm{F}_{\mathrm{T}}\left(\mathrm{t}_{\mathrm{i}}\right)=1-\mathrm{F}^{*} \mathrm{~T}\left(\mathrm{t}_{\mathrm{i}}\right)$ is the probability that a germination will occur. The expression:

$$
\begin{aligned}
& \operatorname{Pg}\left(t_{i}\right)=l \text { i } m \underline{P}\left(\text { of a seed germinating in the time interval }\left(t_{i}, t_{i}+\right)\right. \\
& \left.\qquad \begin{array}{l}
t \\
\quad t \rightarrow 0
\end{array}\right) t
\end{aligned}
$$

describes germination power probabilistically, where $\left.\left(t_{i}, t_{i}+\right) t\right)$ is a finite and infinitesimal time interval (TSENG \& HSU, 1989). Therefore, the power of seed germination is:

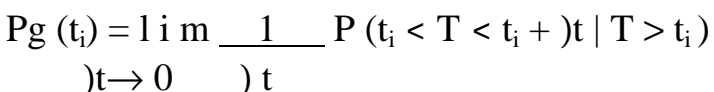

$$
\begin{aligned}
& \text { or, }
\end{aligned}
$$

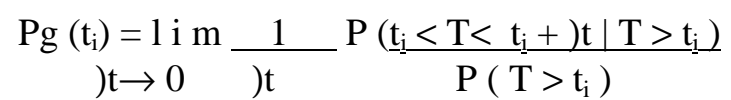

The power of seed germination is related to the remaining seeds which have not yet germinated (Richards, 1959), and is expressed as:

$\operatorname{Pg}\left(\mathrm{t}_{\mathrm{i}}\right)=\left(1 /\left(1-\mathrm{F}_{\mathrm{T}}\left(\mathrm{t}_{\mathrm{i}}\right)\right)\right)(\mathrm{dF} / \mathrm{dt})$, in that $\mathrm{dF} / \mathrm{dt}$ represents the differential of the cumulative function in relation to the time, indicating the instantaneous rate of variation, that is, $\mathrm{f}_{\mathrm{T}}\left(\mathrm{t}_{\mathrm{i}}\right)$ (Carneiro, 1994). Therefore,

$\operatorname{Pg}\left(t_{i}\right)=\left(1 /\left(1-F_{T}\left(t_{i}\right)\right)\right)\left(f_{T}\left(t_{i}\right)\right)$.

The cumulative distribution of Weibull (Weibull, 1951) is defined by the equation:

$\mathrm{F}_{\mathrm{T}}\left(\mathrm{t}_{\mathrm{i}}\right)=1-\exp \left(-\left(\left(\mathrm{t}_{\mathrm{i}}-\mathrm{t}_{0}\right) / \mathrm{b}\right)^{\mathrm{c}}\right)$

with the probability density function,

$\left.\mathrm{dF}_{\mathrm{T}} / \mathrm{dt}=\mathrm{f}_{\mathrm{T}}\left(\mathrm{t}_{\mathrm{i}}\right)=\left[(\mathrm{c} / \mathrm{b})\left(\mathrm{t}_{\mathrm{i}}-\mathrm{t}_{0}\right) / \mathrm{b}\right)^{(\mathrm{c}-1)}\right] \exp \left(-\left(\mathrm{t}_{\mathrm{i}}-\mathrm{t}_{0}\right) / \mathrm{b}\right)^{\mathrm{c}}$

that is used to estimate the frequency at which seeds germinate in each time interval (Carneiro, 1994a). Thus, it is possible to describe the power of seed germination by the potential component of $\mathrm{f}_{\mathrm{T}}\left(\mathrm{t}_{\mathrm{i}}\right)$ in which $\left.\operatorname{Pg}\left(\mathrm{t}_{\mathrm{i}}\right)=(\mathrm{c} / \mathrm{b})\left(\mathrm{t}_{\mathrm{i}}-\mathrm{t}_{0}\right) / \mathrm{b}\right)^{(\mathrm{c}-1)}$. It indicates the conditional probability of the protrusion of the radicle occurring within a defined time interval (Carneiro, 1994a). The relative germination rate is obtained by the logarithm of the same component (Carneiro, 1994a; Takahashi et al., 1996).

\section{Data Analysis}

The data set with cumulative frequencies of seed germination were combined with the distribution of Weibull (Weibull, 1951) using the following parameterization: $\mathrm{Y}=\mathrm{M}(1-\exp (-$ $\left.(\mathrm{t} / \mathrm{b})^{\mathrm{c}}\right)$ ) (Carneiro, 1994a). The additional parameter $\mathbf{M}$ indicates the maximum percentage of seed germination and is necessary due to the aspects related to the censored cases (Brown, 1987; Brown \& Mayer, 1988b; Carneiro 1994a, 1996). The parameter $\mathbf{b}$ is the time to reach $63.21 \%$ of the maximum $(\mathrm{M})$, and the $\mathbf{c}$ is a shape parameter which reflects skewness and accounts for the greater versatility of the distribution (Brown \& Mayer, 1988b). The parameter $\mathrm{t}_{0}$, estimates the lag phase (the time between the start of incubation and when the first seeds germinate) (Brown,1987), and can be removed from the model because its absence does not compromise the evaluation and contributes toward reducing nonlinearity (Carneiro, 1994).

The asymmetries of the parameters were estimated by the Hougaard coefficient (Hougaard, 1985). Values for $\mathrm{g}_{1}$ lower than 0.1 indicate that the parameter estimate is close to 
linear. From 0.1 to 0.25 , the estimate is reasonably close to linearity. Values greater than 0.25 indicate some asymmetry, and values greater than 1.0 are characteristic of totally nonlinear performance (Ratkowsky, 1990). The percentage of bias (Box, 1971) evaluated the stability of these estimates (Ratkowsky, 1990). The curvature of the solution locus in sample space was evaluated by the intrinsic nonlinearity, IN, and the lack of parallelism and inequality of spacing of the parameter lines on the tangent plane at the solution locus were evaluated by the parameter-effects nonlinearity, PE (Bates \& Watts, 1980; Ratkowsky, 1986). The locus represents all possible solutions in the sample space. (Ratkowsky, 1986). The divergence between the tangent plane and the sampling space was evaluated by $\mathrm{F}$ test at the 5\% probability level (Bates \& Watts, 1980; Ratkowsky, 1990).

BMDP®, STATISTIC $®$ and the subroutines of Ratkowsky (1990) were used to estimate the parameters and for calculation the power, probability, and relative rate of seed germination.

The discrimination among the treatments was evaluated by comparing the sums of squares of the residuals obtained for each treatment, with the sum of squares for the set of all observations (Mead et al., 1996).

\section{RESULTS AND DISCUSSION}

The results from combining germination frequencies with the cumulative distribution of Weibull are shown in Table 1. The best performance of the seeds under germination was achieved with the temperature of $30^{\circ} \mathrm{C}$. The maximum percentage (M) was $95.29 \%$, and the time (b) to achieve $60.23 \%(0.6321 \times 95.29 \%)$ was $99.35 \mathrm{~h}$. Under temperatures of $25^{\circ} \mathrm{C}$ and $35^{\circ} \mathrm{C}$, the estimates of $\mathrm{M}$ reached reasonably high values, but the time to $\mathrm{b}$ were $124.3 \mathrm{~h}$ and 127.27 $\mathrm{h}$, respectively. The value of the spread (c) at $30^{\circ} \mathrm{C}$ was 7.19 , indicating that the distribution was close to the peaked normal with a small standard deviation (Dodson, 1984).

The Hougaard coefficient indicates estimates of asymmetry lower than 0.1 and the percent bias less than $1 \%$. At the three temperatures, these parameters had a performance close to linear. (Ratkowsky, 1990). The intrinsic nonlinearity, IN, and those due to parameterization, $\mathrm{PE}$, were not-significant $(\mathrm{P} \leq 0.05)$.

Table 1. Evaluation of the germination performance of seeds Cecropia pachystachya Trec. at three temperatures using the parameters of the Weibull cumulative distribution function.

\begin{tabular}{lllllll}
\hline Temperatures & Parameters & $\begin{array}{l}\text { Hougaard's } \\
\text { Coefficient }\end{array}$ & $\begin{array}{l}\text { Percentage of } \\
\text { bias }\end{array}$ & IN & PE \\
\hline \multirow{2}{*}{$25^{\circ} \mathrm{C}$} & $\mathrm{M}$ & 92.82 & 0.000039 & 0.0006 & & \\
& $\mathrm{~b}$ & 124.3 & 0.014073 & 0.0003 & $0.034 \mathrm{NS}$ & $0.0438 \mathrm{NS}$ \\
\hline \multirow{3}{*}{$0^{\circ} \mathrm{C}$} & $\mathrm{c}$ & 10.31 & 0.044516 & 0.0108 & & \\
& $\mathrm{M}$ & 95.29 & 0.002979 & 0.0023 & & \\
& $\mathrm{~b}$ & 99.35 & 0.019501 & 0.0009 & $0.0588 \mathrm{NS}$ & $0.0617 \mathrm{NS}$ \\
$35^{\circ} \mathrm{C}$ & $\mathrm{c}$ & 7.19 & 0.071130 & 0.0259 & & \\
& $\mathrm{M}$ & 89.66 & 0.015978 & 0.0042 & & \\
& $\mathrm{~b}$ & 127.27 & 0.019106 & 0.0018 & $0.0496 \mathrm{NS}$ & $0.0447 \mathrm{NS}$ \\
\hline
\end{tabular}

$\mathrm{M}=$ Maximum percentage of seed germination; $\mathrm{b}=$ Time until $63,21 \%$ of $\mathrm{M}$ to occurs; $\mathrm{c}=$ The shape parameter indicating the spread of seed germination in time; IN = Intrinsic Nonlinearity; PE = Parameter-effects Nonlinearity; NS = not-significant.

Comparison among treatments, using the residual variance (Table 2) indicated that the performance of seed germination was different at each temperature. Although the differences in the percentages of seed germination were not large, there were differences in performance, with decrease and increase in the time necessary to reach $63.21 \% \mathrm{M}$, and in the estimates of $\mathrm{c}$. 
Table 2. Comparisons of the residual sums of squares of the models adjusted for each separate and combined data set.

\begin{tabular}{ccccc}
\hline Source of variation & RSS & d.f & Ms & F \\
\hline $25^{\circ} \mathrm{C}$ & 11623.0 & 620 & \\
\hline $30^{\circ} \mathrm{C}$ & 31311.3 & 580 & \\
\hline $35^{\circ} \mathrm{C}$ & 37084.3 & 740 & & \\
\hline$\sum$ residual & 80018.6 & 1940 & & \\
\hline Residual for combined data & 279884 & 1946 & & 807.61 \\
\hline
\end{tabular}

The probabilities of seed germination are shown in Fig. 2. It could be seen that at $30^{\circ} \mathrm{C}$, the time to reach $99 \%$ of maximum $(\mathrm{M})$ was $130 \mathrm{~h}$. At $25^{\circ} \mathrm{C}$ and $35^{\circ} \mathrm{C}$, this value occurred only after 150 and $192 \mathrm{~h}$ respectively.

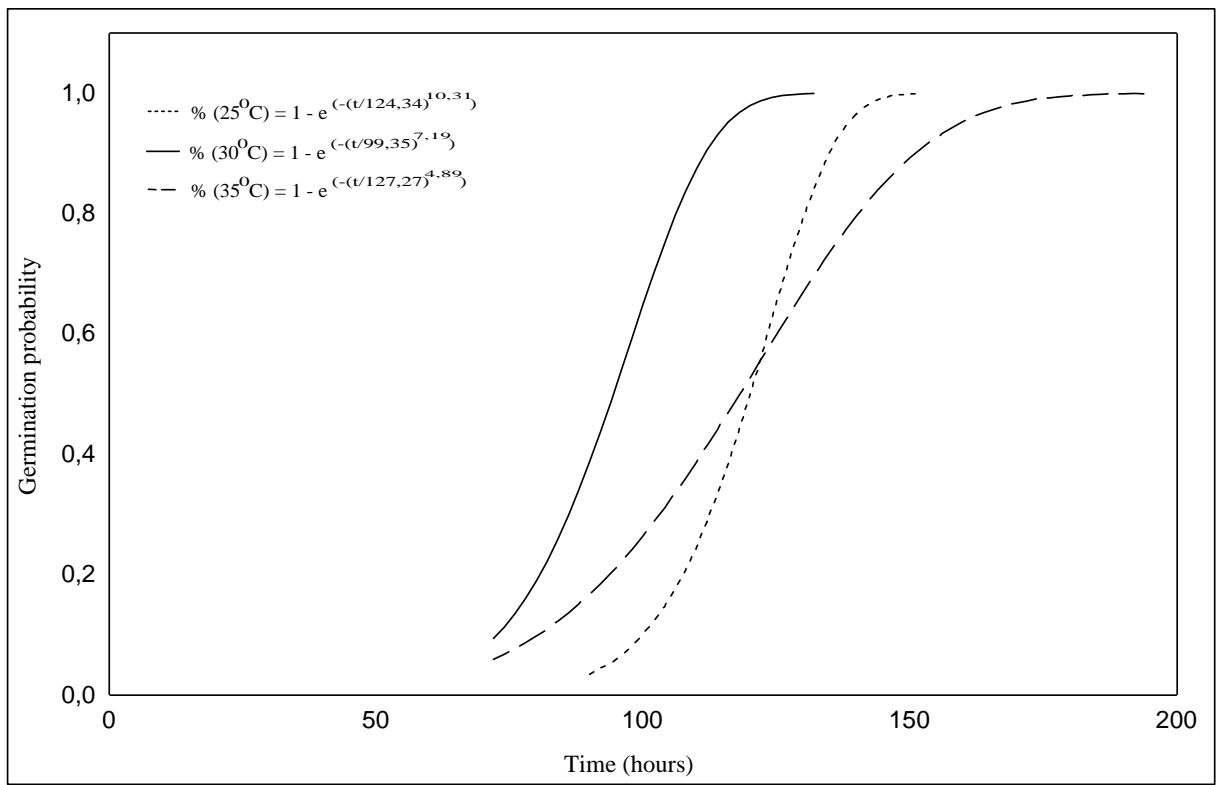

Fig. 2. Probability curves for germination of seeds of Cecropia pachystachya at three temperature

The power of seed germination are presented in Fig. 3. It was found that the seeds which germinated at $30^{\circ} \mathrm{C}$ had a higher germination power than those germinated at $25^{\circ} \mathrm{C}$ and $35^{\circ} \mathrm{C}$. At $30^{\circ} \mathrm{C}$, the seeds germinated over a shorter time interval. Once germination had begun, it proceeded rapidly (Fig. 4). Thus, at this temperature, the chance of germination of a new seed cohort increased in each new period of occurrence of this event, i.e., the cumulative chance of germination ocurrences was high.

The start of seed germination at $25^{\circ} \mathrm{C}$ was delayed, compared to $30^{\circ} \mathrm{C}$ and $35^{\circ} \mathrm{C}$. At $25^{\circ} \mathrm{C}$, radicle protrusions began after $90 \mathrm{~h}$ from the beginning of the test, while at $30^{\circ} \mathrm{C}$ and $35^{\circ} \mathrm{C}$, initial protrusions occurred after $72 \mathrm{~h}$. Nevertheless, once begun, the process was quite rapid, since at $25^{\circ} \mathrm{C}$ the protrusions terminated before that at $35^{\circ} \mathrm{C}$. This could be seen in the steeper slope of the logarithmic curve (Fig. 4). At $35^{\circ} \mathrm{C}$, the relative rate of seeds germination declined, as indicated by the lower slope of the straight line (Fig 4). This slower and more dispersed germination over time was due to the lower value of the parameter $\mathrm{c}$ associated with the value of b. According to Richards (1959), values of $c$ near 3 indicated a deceleration of the phenomenon evaluated. 


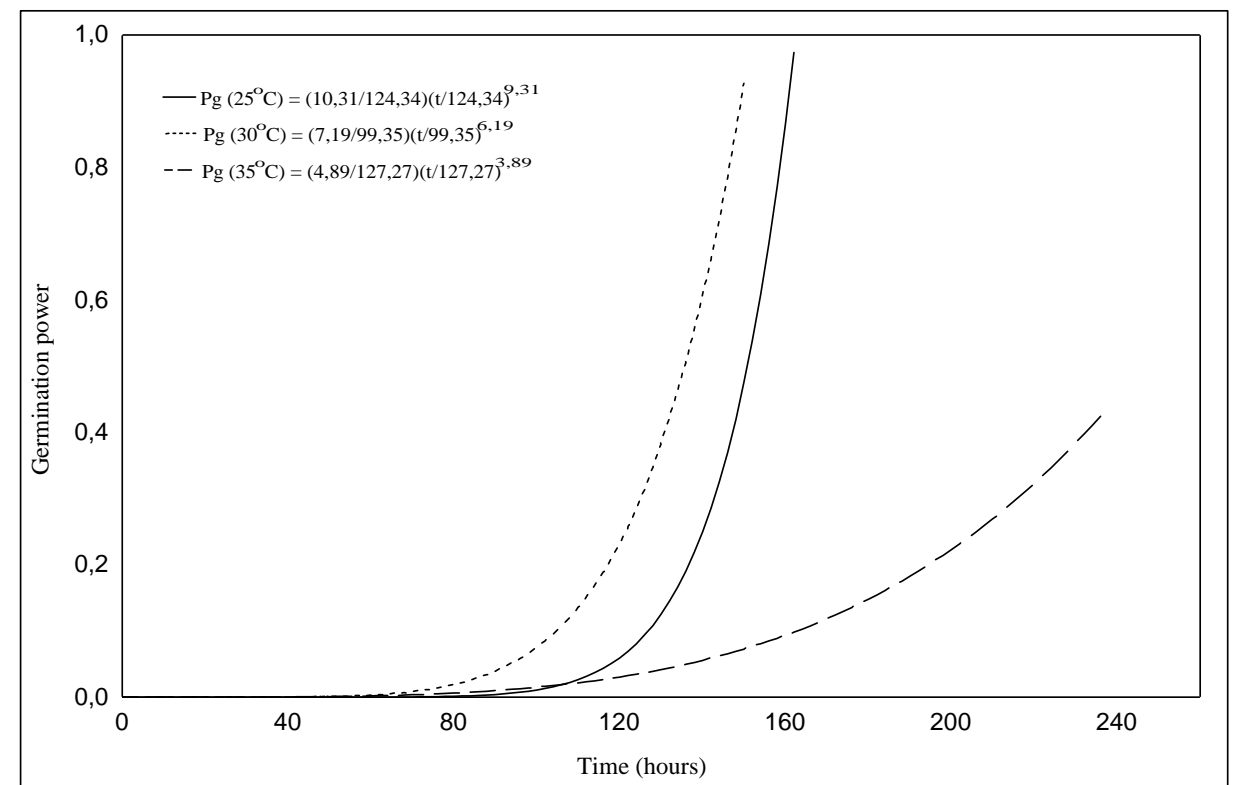

Fig. 3. Curves for the power of seeds germination of Cecropia pachystachya, calculated from estimates of the parameters of the cumulative distribution of Weibull

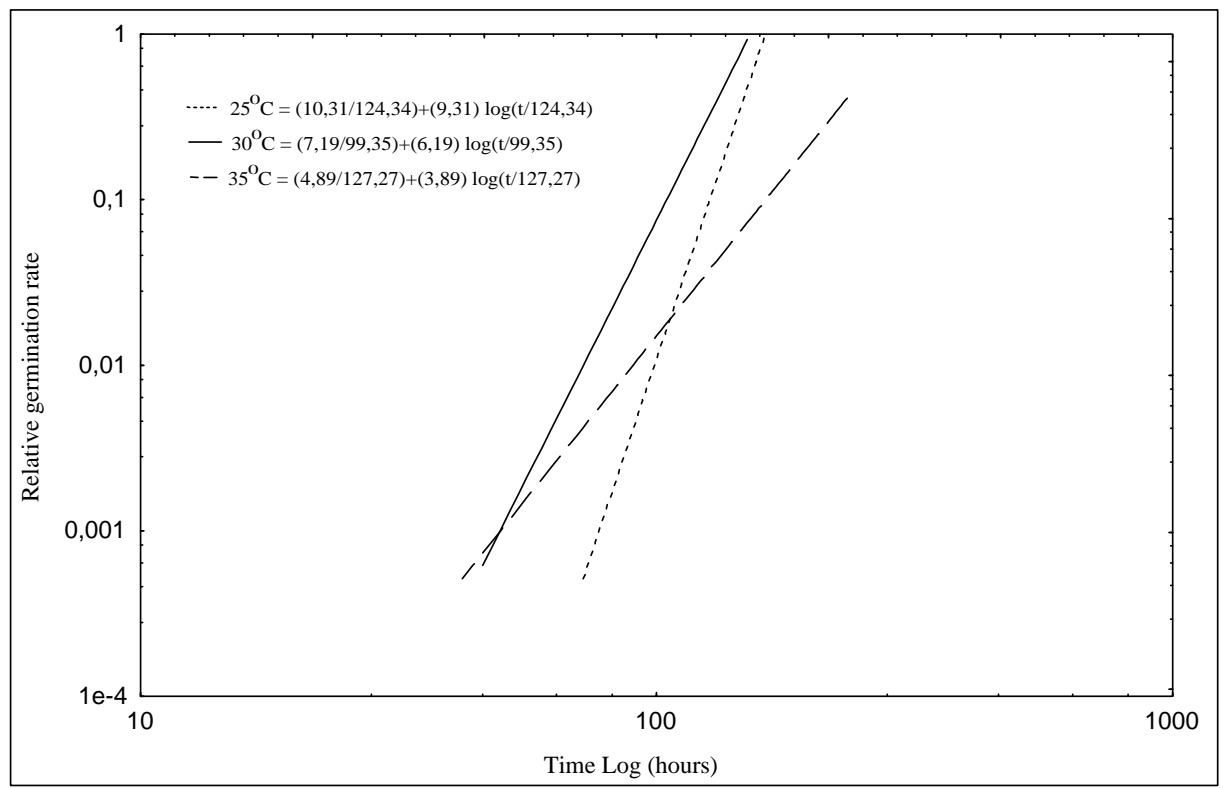

Fig. 4. Relative rate of seeds germination of Cecropia pachystachya, calculated from estimates of the parameters of the cumulative distribution of Weibull

The best performance of seeds obtained at $30^{\circ} \mathrm{C}$, is in agreement with investigators who suggested the thermal interval between $20^{\circ} \mathrm{C}$ and $30^{\circ} \mathrm{C}$ as adequate for seed germination of a large number of tropical and subtropical species (Whitmore, 1982; Borges \& Rena, 1993). Nevertheless, species with widely distributed populations, such as $C$. pachystachya, may show variability in the germination responses according to their geographical distribution (Yousheng \& Sziklai, 1995). Seeds of $C$. pachystachya collected in the region of Moji Guaçú, State of São Paulo, for example, when set out to germinate in beds of sand and in the open air, had only $34 \%$ of germination (Barbosa et al., 1997), a value lower than the results found in present studies. Evaluation of seeds of $C$. obtusifolia at Vera Cruz, Mexico presented $80 \%$ germination at $26^{\circ} \mathrm{C}$ and a strong reduction to $18 \%$ when a temperature of $36^{\circ} \mathrm{C}$ was used (Vazquez-Yanes, 1976). These results do not match with on findings, but are in agreement 
with the decrease in percentage of seed germination at temperatures greater than $30^{\circ} \mathrm{C}$. However, other studies at Vera Cruz, Mexico, using the same species, C. obtusifolia, reported germination percentages higher than $90 \%$ at $25^{\circ} \mathrm{C}$ (Alvarez-Buylla \& Martinez-Ramos, 1990; AlvarezL-Buylla \& Garay, 1994).

The estimates of seed germination obtained here corroborate the observation of Carneiro (1994b), who showed that evaluation of germination of seeds under favourable conditions, and with measurements taken over short time intervals, favour the combination model/data set.

\section{CONCLUSIONS}

The results obtained in this experiment recommend the temperature of $30^{\circ} \mathrm{C}$ for the standard germination test for seeds of Cecropia pachystachya. The temperature of $25^{\circ} \mathrm{C}$, although delayed the time the first radicles protrusions, provided a higher relative rate of seed germination.

\section{ACKNOWLEDGEMENTS}

The authors would like to thank to Denilson do Amaral, Ivair do Amaral and Vitor Paulo de Freitas Cruz for laboratory assistance and Sebastião Rodrigues, for help in the field. Thanks are also due to the Research Nucleus in Limnology, Ichthyology and Aquaculture (Nupelia) and to the Coordination of the Course in Ecologia de Ambientes Aquáticos continentais, for the logistical and financial support.

\section{RESUMO}

Com o objetivo de avaliar o desempenho germinativo de sementes de Cecropia pachystachya Trec., sob diferentes níveis de temperatura, foi realizado um experimento com sementes coletadas em fragmentos da Floresta Estacional Semidecidual Submontana e Aluvial, localizados na planície de inundação do alto rio Paraná. As sementes foram submetidas a temperaturas constantes de $25^{\circ} \mathrm{C}$, $30^{\circ} \mathrm{C}$ e $35^{\circ} \mathrm{C}$. Luzes fluorescentes do tipo "luz do dia" foram mantidas acesas durante todo o período experimental. Cada tratamento consistiu de 10 repetições de 200 sementes distribuídas de maneira uniforme sobre papel especial de germinação, CEL-065, em caixas de plástico transparente do tipo gerbox medindo $11 \times 11 \times 5 \mathrm{~cm}$. As frequiências germinativas foram avaliadas em intervalos consecutivos de duas horas. As freqüências acumuladas foram combinadas com o seguinte modelo da função de Weibull: $\quad \mathrm{Y}=\mathrm{M}\left(1-\exp \left(-(\mathrm{t} / \mathrm{b})^{\mathrm{c}}\right)\right)$. Os resultados indicaram que $\mathrm{o}$ melhor desempenho germinativo foi alcançado com a temperatura de $30^{\circ} \mathrm{C}$. A porcentagem máxima de germinação (M) foi igual a 95,29\%, e o tempo (b) para a ocorrência de uma porcentagem de germinação igual a $60,23 \%$ $(0,6321 \times 95,29 \%)$ foi igual a 99,35 horas. A dispersão das germinações (c) durante o tempo de avaliação foi igual a 7,19, indicando que a distribuição não se afastou muito da normal com pequeno desvio padrão. Ficou evidenciado também, que as estimativas dos parâmetros tiveram um desempenho próximo à linearidade.

\section{REFERENCES}

Alvarez-Buylla, E.R.; Garay, A.A. (1994), Population genetic structure of Cecropia obtusifolia, a tropical pioneer tree species. Evolution, 48 (2), 437-453.

Alvarez-Buylla, E.R.; Martinez-Ramos, M. (1990), Seed bank versus seed rain in the regeneration of a tropical pioneer tree. Oecologia, 84, 314-325.

Bahler, C.; Hill, R.R.Jr ; Byers, R. A. (1989), Comparison of logistic and Weibull Functions : the effect of temperature on cumulative germination of alfafa. Crop. Sci., 29 (1), 142-146.

Barbosa, J.M.; Santos, M.R.O.; Ferreira, M.F.; Peters, J.A. (1997), Efeito da submersão em água sobre o vigor e sobrevivência de sementes de espécies nativas utilizadas em recuperação de áreas degradadas. Paper presented at 3 Simpósio Brasileiro de Recuperação de Áreas Degradadas, SOBRADE: UFV/DPS/DEF, Trabalhos voluntários, 18-24 May, Ouro Preto, Minas Gerais 
Bates, D. M.; Watts, D. G. (1980), Relative curvature measures of nonlinearity. $J . R$. Statist. Soc. B, 42 (1), 1-25.

Borges, E.E.L.; Rena, A.B. (1993), Germinação de sementes. In- Sementes florestais tropicais, eds. Aguiar, I.B.; PinãRodrigues, F.C.M.; Figliolia, M.B. Abrates, Brasília, pp. 83-136.

Box, M. J. (1971), Bias in nonlinear estimation. J. R. Statist. Soc. B, 32 (1), 171-201.

Brown, R.F. ; Mayer, D.G. (1986), A critical analysis of Maguire's germination rate index. J. Seed Technol., 10 (2), 101-110.

Brown, R.F. (1987), Germination of Aristida armata under Constant and Alternating Temperatures and Its Analysis with the Cumulative Distribution as a Model. Aust. J. Bot., 35, 581-591.

Brown, R.F.; Mayer, D.G. (1988a), Representing cumulative germination. 1. A critical analysis of single-value germination indices. Ann. Bot., 61, 117-125.

Brown, R.F.; Mayer, D.G. (1988b), Representing cumulative germination. 2. The use of the Weibull function and other empirically derived curves. Ann. Bot., 61, 127-138.

Budowski, G. (1965), Distribution of Tropical American Rain Forest species in the light of sucessional processes. Turrialba, 15, 40-42

Campos, J.B.; Costa Filho, L.V. (1994), Proposta técnica de implantação da área de proteção ambiental do Arquipélago de Ilha Grande. SEMA/IAP. Curitiba, Paraná.

Campos, J.B.; Souza, M.C. (1997), Vegetação. In-A Planície de Inundação do Alto Rio Paraná: aspectos físicos, biológicos e socioeconômicos, eds. Vazzoler, A.E.A.M.; Agostinho, A.A.; Hahn, N.S. EDUEM : Nupélia, Maringá, pp. 331-342.

Carneiro, J.W.P. (1994a), Avaliação do desempenho germinativo de acordo com os parâmetros da função de distribuição de Weibull. Informativo Abrates, 4 (2), 75-83.

Carneiro, J.W.P. (1994b), Determinação do número de sementes para avaliar o desempenho germinativo de sementes de capim braquiária (Braquiaria brizantha cv. Marandú). Revista Brasileira de Sementes, 16 (2), 156-158.

Carneiro, J.W.P. (1996), Determinação do número de sementes para avaliar o desempenho germinativo de sementes de stévia (Stevia rebaudiana (Bert.)Bertoni). Revista Brasileira de Sementes, 18 (1), 1-5.

Carneiro, J.W.P.; Guedes, T. A. (1995), Influência do estresse térmico no desempenho germinativo de sementes de (Stevia rebaudiana (Bert)Bertoni avaliado pela função de distribuição de Weibull. Revista Brasileira de Sementes, 17 (2), 210-216.

Dodson, B. (1984), Weibull Analysis. ASQC quality Press, Wisconsin, Milwaukee

Dumur, D.; Pilbeam, C.J.; Craigon, J. (1990), Use of the Weibull function to calculate cardinal temperatures in Faba Bean. J. Exp. Bot., 41 (232), 1423-1430.

Figliolia, M.B.; Oliveira, E.C.; Pinã-Rodrigues, F.C.M. (1993), Análise de sementes. InSementes florestais tropicais, eds. Aguiar, I.B.; Pinã-Rodrigues, F.C.M.; Figliolia, M.B. Abrates, Brasília, pp. 137-174.

Hougaard, P. (1985), The appropriateness of the asymptotic distribution in a nolinear regression model in relation to curvature. $J$. R. Statist. Soc. B, 47 (1), 103-114.

Ista. International Seed Testing Association. (1993), International rules for seed testing. Seed Sci. Technol., 21 (Suplement)

Lockley, G.C. (1980), Germination of chockecherry (Prunus virginiana). Seed Sci. Technol., 8 (3), 237-244.

Lorenzi, H. (1992), Árvores Brasileiras: manual de identificação e cultivo de plantas arbóreas nativas do Brasil. Editora Plantarum, Nova Odessa, São Paulo.

Maack, R. (1981), Geografia física do Estado do Paraná. J. Olympio, Rio de Janeiro.

Mead, R.; Curnow, R.N.; Hasted, A.M. (1996), Statistical methods in agriculture and experimental biology. Chapman \& Hall, London.

Popinigis, F. (1977), Fisiologia da semente. AGIPLAN, Brasília.

Ratkowsky, D. A. (1990), Handbook of nonlinear regression models. Marcel Dekker, New York.

Ratkowsky, D. A. (1986), Statistical properties of alternative parametrizations of the von Bertalanffy growth curve. Can. J. Fish. Aquat. Sci., 43, 742-747.

Richards, F.J. (1959), The quantitative analysis of growth. In-Plant Physiology, a treatise, 
ed. Steward, F.C. Academic Press, London, pp. 1-76.

Takahashi, L.; Melges, E.; Carneiro, J.W.P. (1996), Desempenho germinativo de sementes de Stevia rebaudiana (Bert.)Bertoni) sob diferentes temperaturas. Revista Brasileira de Sementes, 8 (1), 6-9

Tseng, S.; Hsu, J.P. (1989), A stochastic analysis of seed germination. Bot. Bull. Acad. Sin., 30, 201-205.

Vazquez-Yanes, A. (1976), Estudios sobre la ecofisiologia de la germinación en una zona cálido-húmeda de México. In- Regeneracion de Selvas, eds. Gomes-Pompa, A.; VazquezYanes, C.; Rodriguez, S.A.; Butanda Cervera, A. Ed. Continental, Mexico, pp. 279-387.

Vieira, D.R. ; Carvalho, N.M. (1994), Testes de vigor em sementes. FUNEP, Jaboticabal, São Paulo.
Weibull, W. (1951), A statistical distribution function of wide aplicability. Journal of Applied Mecanics, 18 (1), 293-297.

Whitmore, T.C. (1982), On patterns and process in forest. In- The Plant Community as a Working Mechanism, ed. New-Mann, E.I. Blackwell Scientific, Oxford, pp. 45-59.

Yousheng, C.; Sziklai, O. (1995), Preliminary study on the germination of Toona sinensis (A.Juss.). Raem. Seed from eleven Chinese provenances. For. Ecol. Manag., 10, 269-281.

Received: October 09, 1998; Revised: October 16, 1998; Accepted: February 08, 1999. 